\title{
Battelle Energy Alliance, LLC, Continuity Readiness Assurance Report - Fiscal Year 2016
}

Sherman Campbell

September 2016

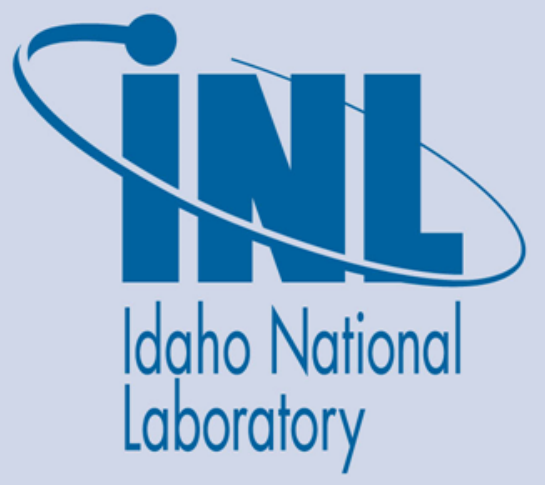

The INL is a U.S. Department of Energy National Laboratory operated by Battelle Energy Alliance 


\section{DISCLAIMER}

This information was prepared as an account of work sponsored by an agency of the U.S. Government. Neither the U.S. Government nor any agency thereof, nor any of their employees, makes any warranty, expressed or implied, or assumes any legal liability or responsibility for the accuracy, completeness, or usefulness, of any information, apparatus, product, or process disclosed, or represents that its use would not infringe privately owned rights. References herein to any specific commercial product, process, or service by trade name, trade mark, manufacturer, or otherwise, does not necessarily constitute or imply its endorsement, recommendation, or favoring by the U.S. Government or any agency thereof. The views and opinions of authors expressed herein do not necessarily state or reflect those of the U.S. Government or any agency thereof. 
INL/EXT-16-39681

Revision 0

\title{
Battelle Energy Alliance, LLC, Continuity Readiness Assurance Report - Fiscal Year 2016
}

\author{
Sherman Campbell
}

September 2016

Idaho National Laboratory Emergency Management

Idaho Falls, Idaho 83415

http://www.inl.gov

Prepared for the

U.S. Department of Energy

Under DOE Idaho Operations Office

Contract DE-AC07-05ID14517 


\title{
Emergency Management
}

\section{Battelle Energy Alliance, LLC, Continuity Readiness Assurance Report - Fiscal Year 2016}

\author{
INL/EXT-16-39681 \\ Revision 0 \\ September 2016
}

Approved by:

Carl J. Farmer

INL Emergency Management Department, Manager 


\section{ABSTRACT}

Battelle Energy Alliance, LLC, the prime contractor for Idaho National Laboratory (INL), provides this Continuity Readiness Assurance Report (CRAR) in accordance with DOE O 150.1, "Continuity Programs." This CRAR documents the readiness of the INL Continuity of Operations Program using emergency response planning, recovery actions, and preparedness activities, and where applicable, summarizes and/or provides supporting information for Fiscal Year 2016. This CRAR also provides goals for Fiscal Year 2017.

Specifically, this CRAR assures the Department of Energy Idaho Operations Office that the emergency capabilities at INL are sufficient to implement the INL Continuity of Operations Plan. 


\section{CONTENTS}

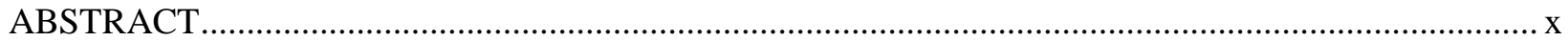

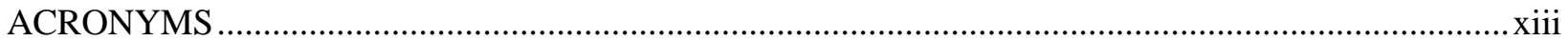

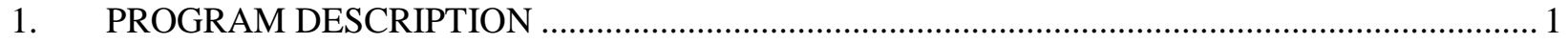

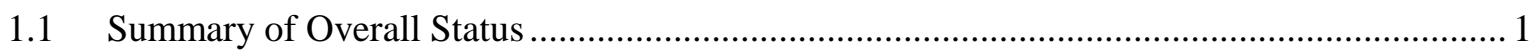

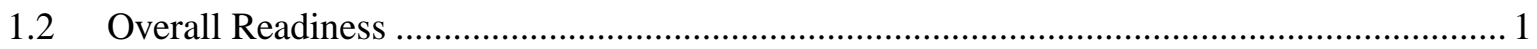

1.3 Limiting Factors Preventing Accomplishment of Essential Functions .................................. 2

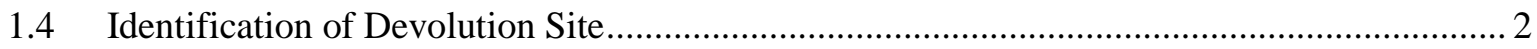

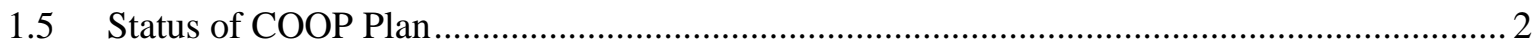

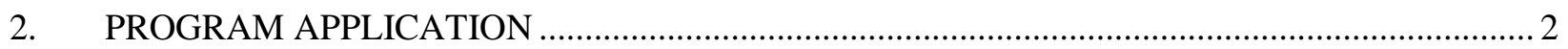

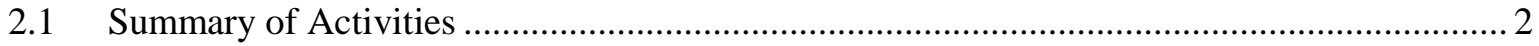

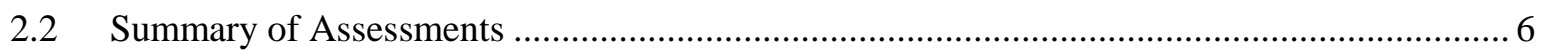

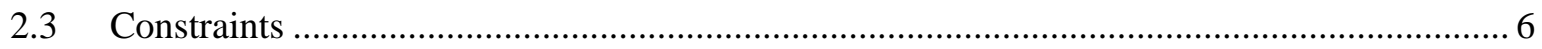

2.4 Program Improvements/Issues/Needs ...................................................................... 6

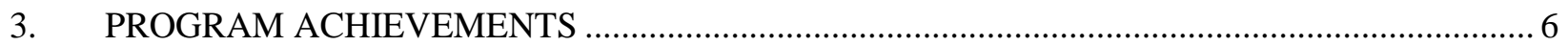

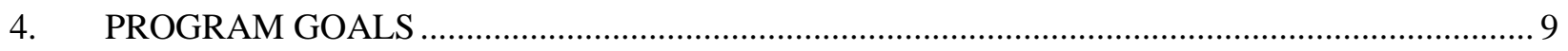

\section{TABLES}

Table 1. Equipment checks, testing, training, tabletop drills, and exercises............................................ 3

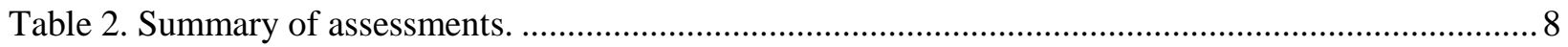




\section{ACRONYMS}

AOF alternate operating facility

BEA Battelle Energy Alliance, LLC

CERG continuity emergency response group

COOP continuity of operations

CRAR Continuity Readiness Assurance Report

DOE Department of Energy

DOE-ID Department of Energy Idaho Operations Office

ESA essential supporting activity

FY Fiscal Year

INL Idaho National Laboratory

LSPT limited scope performance test

MEDCON medical condition

MREs meals ready to eat

NNSA National Nuclear Security Administration

PMEF primary mission essential function

RAM recommended action matrix

VTTX virtual tabletop virtual emergency exercise

WCC Warning Communications Center 


\section{Battelle Energy Alliance, LLC, Continuity Readiness Assurance Report - Fiscal Year 2016 1. PROGRAM DESCRIPTION}

Battelle Energy Alliance, LLC (BEA), is the Department of Energy (DOE) managing and operating contractor for Idaho National Laboratory (INL) at the INL Site near Idaho Falls, Idaho, and Research and Education Campus in Idaho Falls. The INL Continuity of Operations (COOP) Program is an integrated function of the INL Emergency Management Department. PLN-4267, "Idaho National Laboratory Continuity of Operations Plan," was developed in accordance with the applicable requirements in DOE O 150.1, "Continuity Programs," and National Security Presidential Directive-51/Homeland Security Presidential Directive-20. The INL COOP establishes procedures used by BEA during a continuity event. The primary mission essential function (PMEF) is to maintain the safety and security of special nuclear material at INL. The PLN-4267 is an integrated function of the DOE Idaho Operations Office (DOE-ID) and BEA and managed by BEA. It is intended that INL will implement PLN-4267 in conjunction with the DOE-ID COOP Plan (11.OD.02).

PLN-4267 and PLN-2420, "BEA Epidemic/Pandemic Influenza Plan," define the elements of the INL COOP Program.

PLN-4267 applies to all INL personnel and INL programs and essential supporting activities (ESAs) related to the performance of the INL primary mission essential function (PMEF). The objectives of PLN-4267 are to:

- Maintain a high level of readiness

- Protect personnel and visitors from dangerous conditions

- Ensure INL can fulfill its responsibilities for protecting the federal government's legal, financial, and security interests, including critical operational oversight, even when conditions cause INL to operate without its usual support systems and facilities

- Provide at least a minimum level of service required to meet DOE-ID's needs, especially those required at times of local or regional emergencies

- Provide the initial framework for response to any incapacitating event by mission essential personnel to ensure the INL PMEF and ESAs can be performed.

\subsection{Summary of Overall Status}

PLN-4267 establishes the COOP procedures used by BEA and was initially approved by DOE-ID in September 2012. PLN-4267 has been in its fourth year of implementation for Fiscal Year (FY) 2016. FY-2016 provided the opportunity for the development and maturity of the INL COOP Program. With the successful completion of several assessments, tabletop drills, and the annual exercise during FY-2016, BEA is progressively enhancing the capabilities in establishing a robust and sustainable COOP program. Additionally, the INL COOP Program is pursuing the development of a business continuity plan that will address planning considerations for major INL business functions.

\subsection{Overall Readiness}

PLN-4267 supports a high level of confidence in continuing the INL PMEF despite circumstances that may limit access to resources, including personnel, facilities, information systems, and communications. The INL PMEF has line-of-sight to, or supports the performance of, the DOE-ID PMEF and ultimately the DOE mission essential functions/PMEFs and national essential functions, as required 
by DOE O 150.1 and National Security Presidential Directive-51/Homeland Security Presidential Directive-20.

To ensure the overall readiness of the INL COOP Program, the program has established the framework and associated mechanisms for assuring that PLN-4267, implementing procedures, and resources are adequate by ensuring that they are sufficiently maintained, exercised, and evaluated (including assessments and corrective actions) and that appropriate and timely improvements are made in response to needs identified through coordinated and comprehensive COOP planning, resource allocation, training and drills, exercises, and evaluations. Continuous improvement for ensuring overall readiness comes from implementing corrective actions for findings (such as deficiencies, weaknesses, lessons learned, and opportunities for improvement) in all types of evaluations, including both internal and external evaluations.

\subsection{Limiting Factors Preventing Accomplishment of Essential Functions}

Currently, there are no factors that limit BEA's ability to accomplish designated essential functions.

\subsection{Identification of Devolution Site}

Devolution of command and control refers to the situation in which the INL Site is affected to such a degree that it is unable to function. Authority and responsibility must then be transferred. Should this occur, authority and responsibilities are transferred to the agency not affected. In this case, leadership is assured via the orders of succession, under direction of the senior successor, who reconstitutes a continuity emergency response group (CERG). The CERG assumes responsibility for performing the INL PMEF and as many of the ESAs as possible, or notifies DOE of the inability to perform the functions.

\subsection{Status of COOP Plan}

PLN-4267 was implemented in September 2012. PLN-4267 must be reviewed annually, at a minimum, to ensure it is accurate and current. The INL COOP coordinator ensures PLN-4267 is reviewed annually and updated, as necessary. As part of the annual review, the INL COOP coordinator determines whether INL capabilities are sufficient and whether PLN-4267 meets all essential requirements identified in DOE O 150.1. Other aspects of PLN-4267 review include the following:

- Maintaining overall PLN-4267 currency and readiness, to include procedures, equipment, systems, personnel, and rosters

- Addressing and resolving PLN-4267 policy issues

- Advising the INL COOP manager on COOP-related matters

- Coordinating among related plans

- Conducting tests, training, and exercises

- Updating PLN-4267 to incorporate lessons learned from tests, drills, exercises, and any actual events that occurred during the FY.

\section{PROGRAM APPLICATION}

\subsection{Summary of Activities}

Table 1 identifies the equipment checks, testing, training, tabletop drills, and exercises performed during FY-2016 for BEA. Some of the tasks and criteria identified in Table 1 were generated from INL COOP Program goals for FY-2015. 
Table 1. Equipment checks, testing, training, tabletop drills, and exercises.

\begin{tabular}{|c|c|c|c|c|c|}
\hline Type & Subtype & Who & Capability & Task & Criteria \\
\hline $\begin{array}{l}\text { General } \\
\text { employee } \\
\text { awareness } \\
\text { training }\end{array}$ & $\begin{array}{l}\text { Web-based } \\
\text { training / } \\
\text { face-to-face } \\
\text { awareness } \\
\text { campaign }\end{array}$ & $\begin{array}{l}\text { All BEA employees at INL, } \\
\text { including new hires as part } \\
\text { of initial requirements }\end{array}$ & COOP awareness & $\begin{array}{l}\text { Familiarize BEA employees } \\
\text { at INL with COOP alerts, } \\
\text { notifications, accountability } \\
\text { and deployment procedures }\end{array}$ & $\begin{array}{l}\text { COOP concepts, philosophy, } \\
\text { and expectations understood }\end{array}$ \\
\hline CERG training & $\begin{array}{l}\text { Classroom } \\
\text { training }\end{array}$ & INL CERG & $\begin{array}{l}\text { Qualification and } \\
\text { annual refresher } \\
\text { training }\end{array}$ & $\begin{array}{l}\text { Familiarize CERG members } \\
\text { with communications, } \\
\text { available AOF }{ }^{1} \text { resources, } \\
\text { COOP concepts, and CERG } \\
\text { responsibilities and } \\
\text { expectations }\end{array}$ & $\begin{array}{l}\text { COOP requirements and } \\
\text { expectations understood }\end{array}$ \\
\hline $\begin{array}{l}\text { LSPT, }^{1} \\
\text { equipment }\end{array}$ & $\begin{array}{l}\text { Test } \\
\text { (maintenance) }\end{array}$ & $\begin{array}{l}\text { INL COOP coordinator, } \\
\text { INL CERG, and INL } \\
\text { mission critical personnel }\end{array}$ & $\begin{array}{l}\text { Communications and } \\
\text { CERG functions }\end{array}$ & $\begin{array}{l}\text { Check equipment and } \\
\text { documentation for primary } \\
\text { and backup AOFs }\end{array}$ & $\begin{array}{l}\text { All systems are functional, } \\
\text { including primary and } \\
\text { alternate communication } \\
\text { pathways and equipment }\end{array}$ \\
\hline $\begin{array}{l}\text { LSPT, } \\
\text { notification }\end{array}$ & Test & $\begin{array}{l}\text { INL COOP coordinator, } \\
\text { WCC }{ }^{1} \text { and INL CERG }\end{array}$ & $\begin{array}{l}\text { Communications } \\
\text { (Everbridge System) }\end{array}$ & $\begin{array}{l}\text { Test ability to notify CERG } \\
\text { members }\end{array}$ & $\begin{array}{l}\text { Notification is received } \\
\text { (quarterly test) }\end{array}$ \\
\hline LSPT, operations & $\begin{array}{l}\text { Test } \\
\text { (maintenance) }\end{array}$ & $\begin{array}{l}\text { INL COOP coordinator and } \\
\text { INL CERG }\end{array}$ & Essential records & $\begin{array}{l}\text { Ensure essential records are } \\
\text { relevant and accessible at } \\
\text { AOFs }\end{array}$ & $\begin{array}{l}\text { Essential records are } \\
\text { accessible (quarterly } \\
\text { update). However, the } \\
\text { current listing is incomplete } \\
\text { and the primary collection } \\
\text { method is no longer } \\
\text { supported. Currently, this } \\
\text { issue is being worked } \\
\text { towards a more efficient and } \\
\text { complete process. }\end{array}$ \\
\hline $\begin{array}{l}\text { LSPT, alternate } \\
\text { power }\end{array}$ & $\begin{array}{l}\text { Test } \\
\text { (maintenance) }\end{array}$ & $\begin{array}{l}\text { INL COOP coordinator and } \\
\text { INL Protective Force }\end{array}$ & Portable generators & $\begin{array}{l}\text { Check operability of } \\
\text { portable generators and } \\
\text { ensure INL Protective Force } \\
\text { is maintaining equipment }\end{array}$ & $\begin{array}{l}\text { Maintenance schedule is } \\
\text { maintained }\end{array}$ \\
\hline
\end{tabular}


Table 1. (continued).

\begin{tabular}{|c|c|c|c|c|c|}
\hline Type & Subtype & Who & Capability & Task & Criteria \\
\hline Tabletop drill & $\begin{array}{l}\text { Training } \\
\text { development }\end{array}$ & $\begin{array}{l}\text { INL COOP coordinator, } \\
\text { INL CERG; }\end{array}$ & $\begin{array}{l}\text { Maintain essential } \\
\text { connectivity site-wide } \\
\text { until full reconstitution } \\
\text { is established }\end{array}$ & $\begin{array}{l}\text { Respond to a simulated } \\
\text { physical IT attack that } \\
\text { creates serious long-term } \\
\text { dis-connectivity }\end{array}$ & $\begin{array}{l}\text { Problem solving successful } \\
\text { throughout scenario } \\
\text { challenges }\end{array}$ \\
\hline Tabletop drill & $\begin{array}{l}\text { Training } \\
\text { development }\end{array}$ & $\begin{array}{l}\text { INL COOP coordinator, } \\
\text { INL CERG, INL cyber } \\
\text { security }\end{array}$ & $\begin{array}{l}\text { National, virtual cyber } \\
\text { event, impacting all } \\
\text { national labs at } \\
\text { multiple levels }\end{array}$ & $\begin{array}{l}\text { Interact nationally and } \\
\text { locally with cyber security } \\
\text { response personnel to } \\
\text { maintain continuity through } \\
\text { a simulated cyber } \\
\text { interruption }\end{array}$ & $\begin{array}{l}\text { Successful interface with } \\
\text { local and national } \\
\text { responders, MEF and ESA } \\
\text { considerations, manage } \\
\text { impacts and maintain } \\
\text { continuity }\end{array}$ \\
\hline Tabletop Drill & $\begin{array}{l}\text { Training } \\
\text { Development }\end{array}$ & $\begin{array}{l}\text { INL COOP coordinator and } \\
\text { CEMT }\end{array}$ & $\begin{array}{l}\text { Respond to multiple } \\
\text { active shooter scenarios }\end{array}$ & $\begin{array}{l}\text { Identify issues and } \\
\text { challenges posed during } \\
\text { serious physical attacks on } \\
\text { INL employees }\end{array}$ & $\begin{array}{l}\text { Explore the possibility of an } \\
\text { active shooter scenario } \\
\text { evolving into a COOP event }\end{array}$ \\
\hline $\begin{array}{l}\text { LSPT, } \\
\text { emergency } \\
\text { power }\end{array}$ & $\begin{array}{l}\text { Test, } \\
\text { (maintenance) }\end{array}$ & INL COOP coordinator & $\begin{array}{l}\text { Emergency power at } \\
\text { AOF }\end{array}$ & $\begin{array}{l}\text { Check operability of AOF } \\
\text { equipment when supplied } \\
\text { with power by emergency } \\
\text { power facilities }\end{array}$ & $\begin{array}{l}\text { AOF equipment is operable } \\
\text { with emergency power } \\
\text { supply }\end{array}$ \\
\hline $\begin{array}{l}\text { LSPT, COOP } \\
\text { Accountability } \\
\text { process }\end{array}$ & $\begin{array}{l}\text { Test, } \\
\text { (training) }\end{array}$ & $\begin{array}{l}\text { INL COOP coordinator and } \\
\text { INL CERG }\end{array}$ & $\begin{array}{l}\text { COOP Accountability } \\
\text { process }\end{array}$ & $\begin{array}{l}\text { Questionnaire assessment to } \\
\text { gauge the accountability } \\
\text { awareness level of INL } \\
\text { employees }\end{array}$ & $\begin{array}{l}\text { Assessment highlighted an } \\
\text { opportunity to increase } \\
\text { awareness to the lab } \\
\text { population concerning the } \\
\text { COOP accountability } \\
\text { process }\end{array}$ \\
\hline Review & $\begin{array}{l}\text { Internal } \\
\text { Assessment }\end{array}$ & $\begin{array}{l}\text { INL COOP Leadership } \\
\text { Team }\end{array}$ & $\begin{array}{l}\text { COOP plans and } \\
\text { procedures }\end{array}$ & $\begin{array}{l}\text { Crosswalk current } \\
\text { capabilities with plans, } \\
\text { procedures and } \\
\text { commitments }\end{array}$ & $\begin{array}{l}\text { INL COOP plans and } \\
\text { procedures are in alignment } \\
\text { with BEA contractual } \\
\text { expectations }\end{array}$ \\
\hline
\end{tabular}


Table 1. (continued).

\begin{tabular}{|c|c|c|c|c|c|}
\hline Type & Subtype & Who & Capability & Task & Criteria \\
\hline Exercise & $\begin{array}{l}\text { Annual } \\
\text { exercise }\end{array}$ & INL CERG & $\begin{array}{l}\text { Ability to maintain } \\
\text { mission critical } \\
\text { personnel during } \\
\text { multiple transportation } \\
\text { and public safety } \\
\text { disruptions over a long } \\
\text { period of time }\end{array}$ & $\begin{array}{l}\text { Conduct exercise to provide } \\
\text { selected INL CERG } \\
\text { members and supporting } \\
\text { personnel opportunity to } \\
\text { respond to and mitigate a } \\
\text { COOP event }\end{array}$ & $\begin{array}{l}\text { CEMT to initiate } \\
\text { appropriate CERG } \\
\text { notifications and lead CERG } \\
\text { through challenges that } \\
\text { impact the availability of } \\
\text { mission critical personnel, } \\
\text { while maintaining the MEF } \\
\text { and ESAs }\end{array}$ \\
\hline $\begin{aligned}{ }^{1} \mathrm{AOF} & =\mathrm{al} \\
\mathrm{LSPT} & =\mathrm{l} \\
\mathrm{WCC} & =\mathrm{W}\end{aligned}$ & $\begin{array}{l}\text { rating facili } \\
\text { e performan } \\
\text { mmunicatio }\end{array}$ & & & & \\
\hline
\end{tabular}




\subsection{Summary of Assessments}

The INL Issues Management Program ensures issues that have a reasonable potential to cause adverse operational, environmental, safety and health, or quality assurance consequences are documented and resolved in an effective and timely manner. The program is designed to be an integrated BEA process that enables management to understand and prioritize, based on risk and significance, the correction of issues. The program also provides for ensuring that adequate corrective actions are implemented to prevent recurrence of undesirable events or conditions through appropriate causal analysis, corrective action, verification, and follow-up actions.

Issues identified in the INL COOP Program during exercises and actual emergencies are noted and discussed during event critiques. Methods are determined to resolve the concerns and a schedule is prepared to implement the resolution. Once identified, issues are screened and, if appropriate, entered into the Laboratory Protection LabWay for electronic tracking. Corrective action plans are prepared and the issues tracked until resolved.

Table 2 identifies the issues that the INL COOP Program had identified and entered into the Laboratory Protection LabWay during FY-2016.

\subsection{Constraints}

There are no constraints at this time.

\subsection{Program Improvements/Issues/Needs}

Table 2 lists those issues from assessments and evaluations of improvements that the INL COOP Program had identified and entered into the Laboratory Protection LabWay during FY-2016. The issues listed in Table 2 were addressed and closed during FY-2016, with no remaining issues carrying into FY-2017.

\section{PROGRAM ACHIEVEMENTS}

FY-2016 has provided several opportunities for the growth and further development of the INL COOP Program. Several goals set during FY-2015 were successfully completed during the FY-2016 assessment, drills/exercise, and training opportunities.

The ability to continue INL operations during a cyber-event received additional focus during FY2016. Throughout FY-2016, several tabletops focusing on cyber security were successfully conducted. On April 13, INL COOP participated in a Continuity of Operations Virtual Tabletop emergency exercise (COOP VTTX). INL participation further solidified existing collaboration between INL's COOP program and cyber security responders with COOP and cyber security programs across the DOE Complex. The exercise activity was centered on established objectives that provided a learning environment for the participants who responded, via discussion using Adobe Connect, to a simulated cyber security attack scenario. Ongoing cyber-attacks can affect the government's ability to conduct business. Current intelligence indicators point to a potential for attacks on critical infrastructure in the United States. As occurrences of cyber incidents simultaneously affecting multiple federal agencies increase, DOE/NNSA requires streamlined response efforts and enhanced procedures for communication coordination and continuity. The scenario provided an opportunity for INL COOP to validate their continuity plans, policies and procedures.

Simultaneously with preparation for the cyber-event Tabletop, the INL COOP Program increased its training and communication capabilities through the development of a virtual simulation table top tool. The tool has been deployed in both table tops and annual exercise. Additionally, the tool is being used to communicate needs and expectations to INL business stakeholders, aiding the development of a business continuity plan. 
The INL COOP Program provided additional awareness to INL CERG members in the access and use of the COOP accountability contact information. This resource will enable the CERG to provide for accountability remotely during a COOP event. 
Table 2. Summary of assessments.

\begin{tabular}{|c|c|c|}
\hline Issue & Action & Status \\
\hline COOP Accountability Process & $\begin{array}{l}\text { A high percentage of the general population of employees are unaware } \\
\text { of the COOP accountability process. } \\
\text { Action- COOP developed an awareness campaign that contains the } \\
\text { accountability information needed by employees. }\end{array}$ & Closed \\
\hline Harvest Vital Records & $\begin{array}{l}\text { COOP is unable to harvest up-to-date vital records to an external hard } \\
\text { drive. } \\
\text { Action- COOP has met with IT personnel and has created a program } \\
\text { that allows an automated process to back up up-to-date vital records to } \\
\text { an external hard drive. A scalable share point site has been created to } \\
\text { aid in the harvesting of these records. }\end{array}$ & Closed \\
\hline Vulnerability to cyber-attack & $\begin{array}{l}\text { Commence the process of developing approaches by each } \\
\text { mission organization to mitigate effects of possible loss of } \\
\text { connectivity to internet. These approaches were table topped } \\
\text { twice in FY16 with INL IT and cyber security professionals. }\end{array}$ & Closed \\
\hline $\begin{array}{l}\text { Emergency power generators accountability list does not match } \\
\text { serial numbers of generators deployed and in storage }\end{array}$ & $\begin{array}{l}\text { Compiled a corrected list of serial numbers for transmission to } \\
\text { Protective Force Logistics. }\end{array}$ & Closed \\
\hline $\begin{array}{l}\text { COOP Vital Records electronic back-up lacks ability to include a } \\
\text { Table of Contents }\end{array}$ & $\begin{array}{l}\text { An electronic Table of Contents has been developed and } \\
\text { integrated into the new COOP vital records share point site. }\end{array}$ & Closed \\
\hline
\end{tabular}




\section{PROGRAM GOALS}

For FY-2017, the INL COOP Program is looking forward to another successful year of implementing PLN-4267. Realizing there is always room for improvement for the growth of the program, BEA has identified areas to improve proficiency in the way INL manages the INL COOP Program. Along with evaluating new ideas, the program will continue to provide training opportunities and provide assessments of the program to further enhance its capabilities.

INL COOP Program goals for FY-2017, many of which are driven by DOE O 150.1, are as follows:

- Conduct a COOP full-size exercise to test INL COOP response.

- Continue to assist and support implementation of measures to develop an effective response to a cyber-event.

- Train and exercise to CERG responsibilities defined in PLN-4267.

- Provide CERG orientation on responsibilities and equipment.

- Provide all BEA employees at INL awareness training on COOP alerts, notifications, and accountability.

- Review PLN-4267 and update, as necessary, to include incorporating changes in policy (specifically DOE Order 150.1A) and philosophy and managing distribution of plan revisions.

- Maintain and update, as needed, orders of succession of current incumbents and designated successors.

- Update vital records to ensure they are current.

- Update CERG rosters of positions and information, if needed.

- Develop tabletop drill subtypes that consider training development opportunities and/or vulnerability assessments.

- Conduct LSPTs on equipment, the notification process, vital records, emergency power, and the accountability process.

- Continue to pursue a business continuity plan at INL according to the COOP business continuity implementation plan.

- Evaluate and look for ways to improve interaction with the Emergency Operations Center Emergency Response Organization to ensure a strong cohesiveness in preparing for what emergencies might occur in the future.

- Ensure the INL COOP Program has meaningful training activities that encourage participation.

- Follow the development and implementation of DOE O 150.1A, "Continuity Programs," and update PLN-4267, as necessary.

- Improve interfaces and working relationships with all contractors at INL.

- Evaluate and look for ways to improve interfaces and integration opportunities to work with COOP-related organizations. 